\title{
The Modern Educational Domain: Prerequisites and Prospects for Individual Learning Path Development
}

\author{
Katerina Stepanenko \\ Plekhanov Russian University of Economics \\ Correspondence concerning this article should be addressed to Katerina Stepanenko, Plekhanov Russian \\ University of Economics, 36 Stremyanny Lane, Moscow, Russian Federation, 117997. \\ E-mail: valentinova_kate@mail.ru \\ Liya Torosyan \\ Plekhanov Russian University of Economics \\ Correspondence concerning this article should be addressed to Liya Torosyan, Plekhanov Russian \\ University of Economics, 36 Stremyanny Lane, Moscow, Russian Federation, 117997. \\ E-mail: liya-torosyan@yandex.ru
}

\begin{abstract}
This article considers the prerequisites and perspectives of individual learning path (ILP) development in the framework of a student-centered educational paradigm; it defines the rationale of ILP and examines the introduction of project learning technology (PLT) into ILP modeling in higher educational institutions. We claim that identification of students' individual features and compliance with their requirements becomes feasible via the integration of project learning technology into the educational process with relevant pedagogical and computer support. The special emphasis is put on the idea that ILP framing is aimed at enhancing students' autonomy and responsibility for their education, fostering cooperation skills in a close dialogue with other participants in out-of-class projects and teachers. In this scenario an individualized approach is to be implemented in a harmonious solidarity with principles of cooperation and collaboration.

To verify the above-mentioned ideas we conducted an experiment based on cognitive, diagnostic and empirical methods. Two groups of students participated in our research project at the Plekhanov Russian University of Economics in September - November 2015. They are second-year undergraduate students majoring in Economics and studying English as a second language. We designed individual study routes (ISR) for each student and handed them out. The ISR contained progress steps of the project, a set of assignments and deadlines for project submission. The students were provided with opportunity to play an active role devising and altering an ISR. Research findings show that ILP modeling boosts student's motivation to learn English as a second language, enables students' reflexive skills, identifies their individual features while simultaneously developing cooperation and collaboration skills.
\end{abstract}

Keywords: student-centered educational paradigm, individual learning path, individual study route, computer support, pedagogical support, project learning technology, educational domain

The modern educational domain focuses on the concept of individualization and differentiation, which can be implemented via individual learning paths in the context of a student-centered educational paradigm. Nowadays a student becomes the focal point in the educational process, with the teacher's role concentrated only on providing assistance, creating atmosphere for the student's selfdevelopment and advancement. The new vector in education is undoubtedly aimed at enhancement of students' autonomy and responsibility for their own learning process. The current shift of emphasis in the educational models in Russian universities results in a permanent search for new integrative learning 
technologies (collaborative learning, project learning, computer learning, etc.) that expand opportunities for students to choose their own individual learning path, to create a student-centered domain and to boost their autonomy.

\section{Materials and Methods}

\section{Student-Centered Approach Versus Traditional One}

This article examines one of the dominant approaches to language learning: student-centredness, whose essence is in teaching process management aimed at learners' personality development so that they are able to manage their own learning independently and consciously assuming responsibility for the learning outcome. According to the first developer of a student-centered approach in Russia Iraida Yakimanskaya (2013), it is based on the principles of humanization, individualization and differentiation and is aimed at exposure of each and every student's unique individual features .

Student-centered education is based on the synergy of learning, teaching and developing processes. It is a coherent educational process that is substantially different from the traditional one. Comparing student-centered and traditional curriculum David Nunan (1988) emphasizes that the key difference between them is that, "in the former, the curriculum is a collaborative effort between teachers and learners, since learners are closely involved in the decision-making process regarding the content of the curriculum and how it is taught" (Nunan, 1988, p. 2).

A student-centered approach implies changes in the educational domain, shifting from a regimented educational process to a flexible and elective one. These changes are reflected in Table 1.

Evidently, student-centered education means deeper involvement by students in the learning process, more freedom regarding what and how to be taught, opportunities for managing their own learning process, and showing a higher level of autonomy.

The concept of learner autonomy was first elaborated by Henri Holec (1981) and it has currently attained a "buzzword status" (Little, 1991, p. 2) in the context of language learning. Researchers generally agree that learner autonomy can be defined as accountability for the learning process (Benson \& Voller, 1997; Benson, 2003; Holec, 1981; Little, 1991, 1995). Phil Benson and Peter Voller pointed out that in terms of language education autonomy can be implemented in five different ways (Benson \& Voller, 1997, pp. 1-2):

1. by situations in which learners study entirely on their own;

2. by a set of skills which can be learned and applied in self-directed learning;

3. by an inborn capacity which is suppressed by institutional education;

4. by the exercise of learners' responsibility for their own learning;

5. by the right of learners to determine the direction of their own learning..

We assume that an autonomous student should have the following characteristics: has an active position in the educational process, defines learning aims and objectives independently, is motivated to learn a foreign language; analyzes, generalizes and gradually deepens their knowledge on a regular basis. All of these ideas are perfectly materialized in an ILP model.

Table 1

Traditional curriculum versus Student-centered curriculum

\begin{tabular}{lcc}
\hline \multicolumn{1}{c}{ Parameters } & Traditional & Student-centered \\
\hline Form of organization & In-class activities & Both in-class and out-of-class activities \\
\hline $\begin{array}{l}\text { Communication } \\
\text { Responsibility }\end{array}$ & Direct (face-to-face) & $\begin{array}{c}\text { Both direct and indirect (computer-re- } \\
\text { lated communication) }\end{array}$ \\
\hline Teacher's role & Teacher's & Student's \\
\hline Student's role & Leading & Supportive \\
\hline Assignments & Passive & Active \\
\hline $\begin{array}{l}\text { Teacher's engagement degree in the } \\
\text { educational process }\end{array}$ & Standardized & Customized \\
\hline $\begin{array}{l}\text { Student's engagement degree in the } \\
\text { educational process }\end{array}$ & High & Low \\
\hline Autonomy degree & Low & High \\
\hline
\end{tabular}




\section{Individual Learning Path}

There are many definitions of ILP (Khutorskoy, 2005; Sysoev, 2013; Yakimanskaya, 2013). However, its central tenets are as follows: ILP is a way for students to achieve educational goals and learning objectives customized to their needs and requirements, incentives and interests.

Transition to an individual learning path can be stipulated by:

- Multilevel foreign language competence in a group (batch, course);

- Rising percentage of students with special needs;

- Entry of students who are forced to miss classes due to their participation in sporting tournaments;

- Accessibility of computer assisted instruction;

- Humanization of education, which presumes consideration of students' individuality.

In higher educational institutions, a student's transition to the ILP includes several stages (Podlasy, 2007):

- Student readiness assessment to study and bear responsibility for the educational results in the framework of the ILP, executed by leading professors;

- Student's willingness to shift to the ILP model.

It should be noted that an ILP can be designed for a short or long period of time (module, semester, academic year). ILP could be materialized in the form of individual study route (ISR), which is to be designed for each student. An ISR structure includes (an example of an ISR prototype is presented in Appendix 1):

1. Student's name;

2. Course, group;

3. Name of academic subject;

4. Teaching material (course book, tests, workbook, additional literature, plans, schemes, lecture notes, etc.);

5. Assignments;

6. Deadline for assignments submission;

7. Progress tutorials (intramural or extra mural via e-mail, videoconferences with project work participants and teachers, chats, blogs, posts and reposts);

8. Credit points.

\section{Project Learning Technology}

As mentioned above, individualization and differentiation facilitate meeting the student's individual unique features, needs and requirements. Pedagogical science has been frequently using terms such as "self-actualization, self-assessment, selfcontrol", etc. However it should be noted that the notion of "self" is a synergy effect of joint efforts produced by teamwork. To our mind, the project method is a further step in the development of an education in cooperation that has proven its unique autonomy and success. Consequently, the project is an individual learning product, which is a key factor in choosing this very technique for educational purposes in institutions of higher education. As project work advances, the learning process for a student becomes more valuable and self-motivating. It should be mentioned that such assignment type requires significant content knowledge in order to achieve the following results: problem determination, solution options, possible development scenarios.

We completely share the thesis of the first developer in this field in Russia, Evgenia Polat (2007), that the project method is a core of student-centered education. It can be used at any stage of learning process and is an ideal educational technique in higher education (Stepanenko, 2011) as it meets all the main teaching aims in the current emphasis on individual activity, enhancement of students' autonomy, and plans for individual-centered routes to learning. Marina Bukharkina and Evgenia Polat (2007) highlight the most significant project technology features:

- Dominant activity types: role-playing, informative, prospect-orientated;

- Subject-packed: mono project, crosscurriculum project;

- Principles of activity coordination in the process of project work: direct coordination (face-to-face), indirect coordination (via videoconferences, chats, e-mail, etc.);

- Status report of project progress;

- Duration of project execution: short-term, long-term.

Project work process requires different activity types, such as cognitive, communicative, practical and presentational. One of the positive consequences in higher education of these activities is the organization of work in groups that, in the context of current global computerization and student autonomy, plays an important role in learning. Project work in groups implies cast breakdown, segmented task performance and joint efforts of all participants towards a common goal. We deem it advisable to include project work as one of the creative and research activity types into plans for individual learning routes for senior students. Coordination of students project work can be executed indirectly via Internet and Intranet technologies.

\section{Pedagogical Support for ILP}

The modern educational domain is constantly changing due to social development and innovations (Egorychev, Fomina, Mardochaev, Rybakova, Sizikova, 
2014), changes that are not always positive. One result is increasing tension within learning and teaching processes, making relevant pedagogical support ever more crucial (Torosyan, 2013). Providing proper pedagogical support of ILP implies an array of competencies that a teacher should acquire for successful task performance. An analysis of the research (Isaev, Shiyanov, \& Slastyonin, 2014; Markova, 1996; Yakusheva, 2014) allows us to highlight several pedagogical skills which determine teacher's professional competency:

- Didactic skills - general pedagogical skills to define learning tasks and objectives; to choose adequate forms, methods, techniques and strategies; to be able to convey personal knowledge, training and educational technologies in a new pedagogical situation; to be able to find solutions for each pedagogic scenario;

- Organizational-pedagogical skills - general pedagogical skills to plan, to choose optimal tools for pedagogic impact and cooperation, to shape an individual professional route for learners;

- Organizational-methodical skills - skills to create learning interest, to organize educational-professional activity for students, to build a positive rapport in a community, to organize team work;

- Communicative skills - general pedagogical skills which include perceptive, evocative and declamatory skills that achieve pedagogical objectives in the framework of constant pedagogical cooperation;

- Prognostic skills - general pedagogical skills which include the ability to forecast individual and community development, pedagogical progress, students' learning difficulties, results of methods, techniques, learning and training tools application;

- Reflexive skills - ability for self-cognition, self-assessment of professional activity and behavior, self-actualization;

- Special skills - single-discipline skills (fieldspecific knowledge).

Use of information technology (IT) in learning is part of the strategic mission of modern education. IT literacy is an integral part of a teacher's professional competency and is a determinative factor for proper ILP pedagogical support in the context of modern educational development trends. IT competency is defined by a group of authors (Gritskov, Evstigneev, Sysoev, 2008) as high proficiency in new information technologies, comprehension of their application range in learning and critical attitude towards posted information. Svetlana Trishina (2005) determines IT competency as an integrative individual feature which is a result of processes such as informational selection, content uptake, processing, transformation, generation of a special type of subject-specific knowledge which allows for production, uptake, forecasting and optimal solutions in different life spheres.

Disaggregating the composition of IT competency has been examined by parts of the scholarly literature. Trishina's position (2005) is useful to our argument as she points out the following structural components:

- Cognitive: processes of analysis, comparison, generalization, fusion, information processing and storage;

- Value-motivating: personal incentives towards professional activity, mandatory competency level attainment;

- Technical-technological: skills and abilities to work with IT flows using information technologies;

- Communicative: knowledge, comprehension, use of foreign languages and other semiotic systems, communication types (verbal, nonverbal) and information transfer;

- Reflexive: individual self-regulation, selfconsciousness and self-realization.

Consequently, implementation of IT learning in higher educational institutions is correlated with the introduction of absolutely new educational approaches, remapping of procedural roles and alteration of top priorities that profoundly change both student's and teacher's opportunities in choosing a learning path and soundly enhances student's autonomy.

\section{Computer Support of ILP}

We are currently facing a new revolutionary stage in the development of communication. With respect to learning, the current emphasis on variability and diversity favors individual paths that use computer technologies, supported by such modern learning trends as dynamism, possibility of individual-tuition and educational differentiation. The "autonomous student - teacher" collaboration with the use of e-technologies can draw on different computerrelated communication forms:

- E-mail;

- Mailing list;

- Group projects;

- Blogs;

- Videoconferences;

- Chats;

- Forums;

- Guest books;

- Web portal.

E-mail is a traditional form of electronic communication, which boosts effective dialogue among students and teachers. In addition to transferring information about assignments, forwarding materials, 
individual progress tutorials, students and teachers can also interact in written form on any chosen subject. Moreover, it has become extremely popular among learners to shape their own mailing lists that create additional opportunities for communication.

Group projects are one of the most effective working methods that profoundly enable the development of communicative competency. They allow students to create their own educational domain, to hold videoconferences to discuss a project concept with the participation of their tutor, to frame e-guest books and/or forums with third party participants for the purpose of sharing different opinions concerning a research topic.

\section{Web Portal (Using E-Docflow and E-Education Tools)}

The web portal with the content management system is the core of a university information system, providing access to the Internet and Intranet, human resources management, documentation flow (graphic description of business processes), learning materials (including tests) and creating an interface with video classes (webinars and other distant learning tools) and different infrastructural departments (accounts office, HR office, etc.). Web e-docflow applications allow for the framing of visual business processes that also can be used as a basis for educational process management. Collective tools are easy to use for the organization of students' project work.

Vyacheslav Zhirov (2015) identified that main web portal components as:

- Global database of all employees;

- Employee personal online account with expanded e-possibilities (personal data, photos and video materials, blog, personal schedule, etc.);

- General information about a company, its history, mission, values and corporate culture;

- Official news (orders, directives, rules);

- Full-text search engine with all the online information posted in Russian and English;

- Russian and English morphology support;

- Possibility to create working or project groups for joint brainstorming and discussion of operating and non-operating tasks;

- Discussion of ongoing problems (forums, webmessenger);

- Tasks and instructions for group members, planning, implementation control;

- Documents archive for a group, versions and alterations control, work with group documents via Windows Explorer, for example, and office applications;

- Photos and video materials;

- Library stock of course books and study guides for university teachers;

- Library stock of faculties' research papers;

- Web references to sites of partner universities and e-mails of their administration;

- Cooperation with partner universities' web portals;

- Cooperation with companies' web portals;

- Possibility to watch lectures of Russian and foreign professors online.

The following positive features of the abovementioned communication forms can be:

- Possibility to form communication skills in a specific environment. For example, during videoconferences participants meet one another; virtual barrier and unusual atmosphere enable members' cooperation.

- Skills practice to present projects in a virtual environment.

- Text messages can be considered as language material and extra-curricula activity while discussing topics in forums/guest books/chats. Posted messages can become a part of e-course book, e-lectures, etc.

- Chats motivate students to learn foreign languages more intensively because, firstly, chatting is usually informal and interesting and, secondly, its unconventional educational form attracts many more learners. In addition, chats develop students' writing skills, enable them to share ideas on line, to get feedback from their group mates and teachers.

- Blog communication lacks the emotional features of live communication. Consequently, the autonomy removes psychological inhibition, liberates a person, and creates an atmosphere where students feel confident and empowered. Blogs are essential tools for explanation, course topics comments, progress tutorials, knowledge management and educational organization, writing skills training, reading and pronunciation learning (especially for short and intensive programs), business language training (imitation of company work, business environment simulation), etc.

- Students perform real tasks (that are neither exercises nor artificial situations), work with different databases in order to find a solution for a particular scenario that would be supported by program applications including real practice.

- Students get new knowledge teaching one another as well with the use of communication technologies and, of course, the Internet.

\section{Results and Discussion}




\section{Hypotheses and Methodology}

The first hypothesis is that ILP implementation into the educational process will be based on the identification of students' unique individual features. The second hypothesis is that the proposed ILP will serve as the most efficient tool to motivate students to learn English as a foreign language. In order to prove these hypotheses the following methods were applied:

- Cognitive (analysis and synthesis of methodological and psychological-pedagogical literature; analysis of foreign language educational programs, course books and guidebooks for bachelor students);

- Diagnostic (students' questionnaires, learning process analysis);

- Empirical-experimental (quantitative and qualitative analysis of research phase results);

- Statistical processing of obtained results.

\section{Participants and Procedure}

The research phase of the project began on September 10, 2015 in Moscow and lasted 9 weeks (one module), with 50 students (32 male and 18 female, aged 18-20, majoring in Economics) enthusiastically participating in all stages of the research. The underlying idea was that the synergetic effects of teamwork could produce the self-actualization of an autonomous student and enable him or her to critically evaluate and reassess results of project work. The participants (second-year bachelor students studying at Plekhanov Russian University of Economics at the B1-B2 level of English in the CEFR for languages) were divided into 2 groups, with 6 teams in the first group and 4 teams in the second one. After this stage, individual study routes were designed and handed out to each participant. These routes contained progress steps of the project, a set of assignments and deadlines for project submission and the students were able to independently choose a market segment, a product/ service and initial budget. Within the project work, participants allocated responsibilities on their own and were provided with opportunities to modify their ISR. Video clips with project presentations (2 groups, 10 teams) were posted online on a social network, VKontakte. Students voted online for the best business plan for a start-up company, the outline of which included the following steps:

1. Description of market niche for the company.

2. Description of the unique selling points of a product or service.

3. Analysis of advantages over competitors' comparable products/services.

4. Financial road map design.

5. Results and conclusions.
Moreover, learners actively participated in discussions of project work results and shared comments why this or that project was worth being awarded. The results are listed below in Table 2 .

Table 2

Online voting results

\begin{tabular}{cccc}
\hline \multicolumn{2}{c}{ Group 1 } & \multicolumn{2}{c}{ Group 2 } \\
B2 level students & \multicolumn{2}{c}{ B1level students } \\
\hline Team № & $\%$ & Team № & $\%$ \\
\hline 1 & 38,1 & 1 & 31,2 \\
\hline 2 & 38,1 & 2 & 31,2 \\
\hline 3 & 9,5 & 3 & 25,4 \\
\hline 4 & 9,5 & 4 & 12,2 \\
\hline 5 & 4,8 & & \\
\hline 6 & 0 & & \\
\hline
\end{tabular}

Furthermore, a survey was conducted among the same groups. The predominant aim was to identify the possible outcomes of the project learning method (PLM) in the learning process and determine its correlation with top teaching priorities, such as the development of motivation and professional selforientation. We defined two questions that required students to analyze the motives, reasons and possible outcome of PLM realization:

1. "Do you think that the incorporation of project learning technology can be considered as a motivating factor to learn foreign languages in higher education?" (see Figure 1);

2. «Does project learning technology implementation bring out your unique features? (see Figure 2).

Possible answers were: 'Yes", "No", "Neither agree nor disagree". These survey questions would enable students to consolidate their ideas, thoughts and individual educational experience, to think more thoroughly about the genuine factors that motivate them to learn foreign languages beyond in-curriculum activities.

Reviewing the data we registered the following results. Figure 1 illustrates that $76 \%$ of students considered the innovative method as a positive motivating factor for their individual learning process; while $13 \%$ expressed a negative attitude towards implementation of the abovementioned method and only $11 \%$ gave neutral answers. The second question targeted students' assessments of their disposition towards choosing PLM as the most effective tool to identify their unique learning features, taking into account variability and diversity. The correlation between answers was practically similar to those given to the first question. Figure 2 illustrates that $78 \%$ of students preferred PLM to discover their individual 
peculiarities, $11 \%$ expressed a negative view and $11 \%$ gave a neutral answer.

We believe that the positive feedback can be considered as a sound argument proving our hypotheses and can serve as the basis for further research and implementation of the proposed models in teaching practice.

\section{Conclusion}

The Russian modern educational domain has been developing in a different direction and is focused on the concepts of humanization, individualization, differentiation, informatization, etc. Our analysis leads us to conclude that ideas of collaboration and cooperation are reflected in new educational technologies, which can best meet learners' individual features and requirements. The proposed educational model implies implementing ILP with the application of project learning technology and IT support. This choice is not accidental. The project learning method stimulates individual self-actualization and simultaneously develops teamwork, cooperation and collaboration skills. Modern information technologies offer path breaking opportunities and frontiers for the management of learning, including distant education

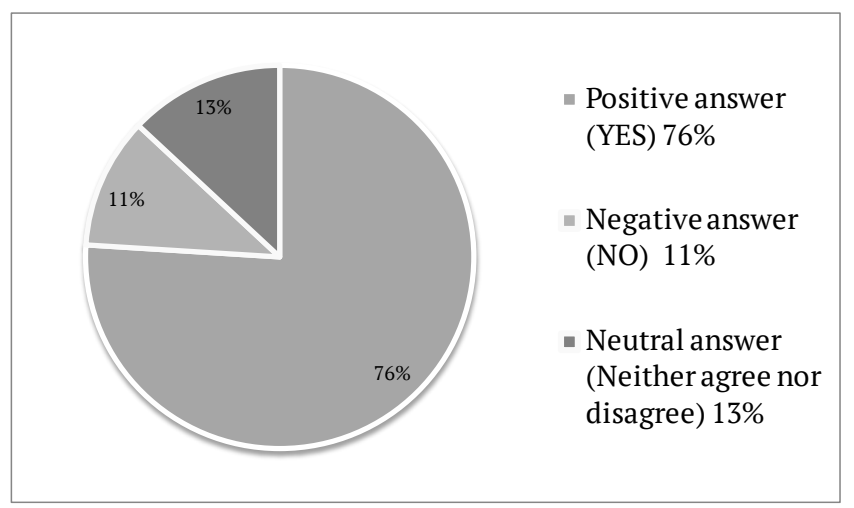

Figure 1. Opinion poll results for the first question.

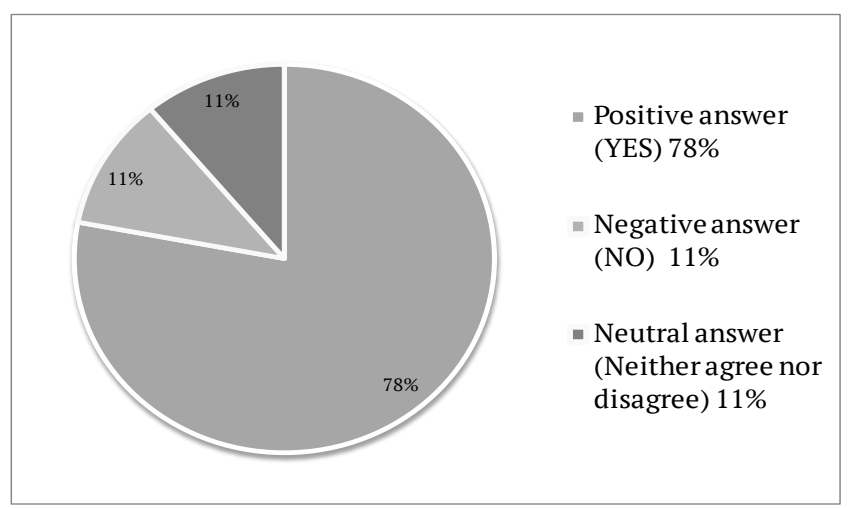

Figure 2. Opinion poll results for the second question. and individual routes. It seems extremely important to complete technical tools with live human content, to preserve "student-teacher" collaboration in the context of technical and technological progress. The very incorporation of project technology into ILP would allow the implementation in practice of the ideas and concepts of pedagogical and computer support, individualization and cooperation in the framework of a student-centered educational paradigm.

\section{References}

Benson, P. (2003). Learner autonomy in the classroom. In D. Nunan (Ed.), Practical English language teaching. New York, NY: McGraw Hill.

Benson, P., Voller, P. (1997). Autonomy and independence in language learning. London, UK: Longman.

Egorychev, A. M., Mardochaev, L. V., Rybakova, A. I., Fomina, S. N., \& Sizikova, V. V. (2014). Society and education in the early of XXIth century: Integration of tradition and innovation. Journal of Advanced Research in Law and Economics, 2(10), 82-91.

Gritskov, D. M., Sysoev, P. V., Evstigneev, M. N. (2008). Pedagogical staff training for developing Internet recourses in a foreign language. In Materials of the XII International Research and Practice Conferenceexhibition (pp. 33-35). Tambov, Russia: Tambov State University named after G.R. Derzhavin.

Holec, H. (1981). Autonomy and foreign language learning. Oxford, UK: Pergamon.

Khutorskoy, A. V. (2005). Student-centered education. How to teach differently? Moscow, Russia: VladosPress.

Little, D. (1991). Learner autonomy 1: Definitions, issues and problems. Dublin, Ireland: Authentik.

Little, D. (1995). Learning as dialogue: The dependence of learner autonomy on teacher autonomy. Pergamon, 23(2), 175-181.

Markova, A. K. (1996). Psihologija professionalizma [Psychology of professionalism]. Moscow, Russia: Znaniye.

Nunan, D. (1988). The learner-centered curriculum. Cambridge, UK: Cambridge University Press.

Podlasy, I. P. (2007). Pedagogika. Teorija i tehnologii obuchenija [Pedagogics. Theory and technology of education] (2nd ed.). Moscow, Russia: Vlados.

Polat, E. S., Bukharkina, M. Y. (2007). Sovremennye pedagogicheskie i informacionnye tehnologii v sisteme obrazovanija [Modern pedagogical and information technologies in the system of education]. Moscow, Russia: Academy.

Slastyonin, V. A., Isaev, I. F., \& Shiyanov, E. N. (2014). Pedagogika [Pedagogics]. Moscow, Russia: Academia. 
Stepanenko, K. A. (2011). Metod uchebnogo proekta kak primer ispol"zovanija innovacionnoj pedagogicheskoj tehnologii $\mathrm{V}$ vysshej shkole [Project of learning method as an example of innovative technology implementation in higher school]. In Materials of RC "Sociosphere" conferences (Vol. 8, pp. 113-115). Prague, Czech Republic: Vedecko vydavatelske centrum Sociosfera-CZ s.r.o.

Sysoev, P. V. (2013). Obuchenie po individual'noj traektorii [Individual education path]. Language and Culture, 4(24), 121-131.

Torosyan, L. D. (2013). Jelektronno-metodicheskoe soprovozhdenie samostojatel'noj raboty bakalavrov po obucheniju professional'no-orientirovannomu chteniju [Computer-assisted methodological support for bachelors' independent work in vocationally-oriented reading]. Journal of Secondary Professional Education, 10, 22-24.

Trishina, S. V. (2005, September). Informacionnaja kompetentnost' kak pedagogicheskaja kategorija
[Information competence as a pedagogical category]. Eidos. Retrieved from http://www.eidos. $\mathrm{ru} /$ journal/2005/0910-11.htm

Yakimanskaya, I. S. (2013). Osnovy lichnostno orientirovannogo obrazovanija [Basics of studentcentered education] (2nd ed.). Moscow, Russia: Binom. Laboratoria znaniy.

Yakusheva, S. D. (2014). Osnovy pedagogicheskogo masterstva $i$ professional'nogo samorazvitija [Basics of pedagogical excellence and professional development]. Moscow, Russia: Forum; Infra.

Zhirov, V. F. (2010, April). Innovacionnye vozmozhnosti informacionnyh tehnologij pri realizacii kompetentnostnogo podhoda v vysshem jekonomicheskom obrazovanii [IT innovative opportunities for implementing competencybased approach in higher economic education]. Eidos. Retrieved from http://www.eidos.ru/ journal/2010/0423-3.htm 


\section{Appednix A}

INDIVIDUAL STUDY ROUTE

STUDENT'S NAME

GROUP, COURSE

ACADEMIC SUBJECT

TEACHER

START AND TERMINATION DATE

ACADEMIC HOURS

PROGRESS TUTORIALS (Date and time)

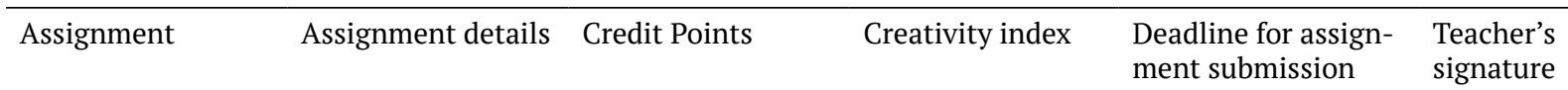

Project 1.

\begin{tabular}{|c|c|c|c|c|c|}
\hline Motivation & excellent & good & average & poor & weak \\
\hline Independent learning & excellent & good & average & poor & weak \\
\hline Language ability & excellent & good & average & poor & weak \\
\hline Homework completion & excellent & good & average & poor & weak \\
\hline
\end{tabular}

General comments and advice for continued studies

Teacher's signature

Dean's signature

Date 